\title{
INTERLEUKIN-8 AND LARYNGEAL SQUAMOUS CELL CARCINOMA
}

\author{
Michele Grasso ${ }^{1}$, Massimo Ralli1 ${ }^{*}$, Griselda Agolli ${ }^{1}$, Marco Fiore ${ }^{2}$, Mauro Ceccanti ${ }^{3}$, Paola Tirassa ${ }^{2}$, \\ Marco de Vincentiis ${ }^{4}$, and Antonio Greco ${ }^{1}$ \\ ${ }^{1}$ Department of Sense Organs, Sapienza University of Rome, Italy \\ ${ }^{2}$ Institute of Cell Biology and Neurobiology, IBCN-CNR, Rome, Italy \\ ${ }^{3}$ Centro Alcologico Regione Lazio, Rome, Italy \\ ${ }^{4}$ Department of Oral and Maxillofacial Sciences, Sapienza University of Rome, Italy
}

Laryngeal squamous cell carcinoma (LSCC) is the second most common neoplasm of the upper aerodigestive tract after cancer of the oral cavity. Over the past two decades, even though patients have benefited greatly from the latest advances in surgical techniques, chemotherapy and radiation therapy, the survival rate of LSCC has not improved significantly. It is reported that changes in the expression of cytokines and growth factors have implications in the malignant transformation of many cancers including head and neck squamous cell carcinoma and, more recently, LSCC. It has been hypothesized that some of these cytokines may be used as additional diagnostic markers in the sera of patients because of their excessive production by the tumor cells. This could be of great value since there are currently no reliable markers to predict either tumor development or relapse. Interleukin- 8 (IL-8), a chemokine (C-X-C motif) ligand 8 (CXCL8), is now reported to play an important role in cancer invasion, angiogenesis and metastasis. Recent studies have shown an increased concentration of $I L-8$ in patients with LSCC and a positive association with lymph node metastasis and T classification. Interleukin-8 levels were not significantly associated with shorter overall survival and cancer progression-free survival. The investigation of the mechanisms of origin, invasion, and metastasis of the cancer is one of the emergent and most promising scientific fields in head and neck cancer, especially in LSCC. Biomarkers such as IL-8 could have a role as a screening test and as a support of the clinical decisions for appropriate therapy and postoperative care in individual patients. Biomed Rev 2018; 29: 47-55

Keywords: interleukin-8, laryngeal squamous cell cancer, head and neck cancer, chemokines, cancer

Received 14 December 2018, revised 21 December 2018, accepted 22 December 2018.

* Corresponding author: Dr Massimo Ralli, Department of Sense Organs, Sapienza University of Rome, Viale del Policlinico 155, Rome 00186, Italy

Tel: +39 064997 6808, Email: massimo.ralli@uniroma1.it 


\section{INTRODUCTION}

Laryngeal squamous cell cancer (LSCC) is the second most common neoplasm of the upper aerodigestive tract after cancer of the oral cavity (1). Over the past two decades, even though patients have benefited greatly from the latest advances in surgical techniques, chemotherapy and radiation therapy, the survival rate of LSCC has not improved significantly $(2,3)$. In 2016, an estimated 13,430 new cases of laryngeal cancer have been diagnosed, with approximately 3620 patients dying from the disease. Laryngeal squamous cell cancer occurs more commonly in men than in women ( 5.8 cases per 100.000 vs 1.2 per 100.000 , respectively). In addition, there are racial disparities observed in laryngeal cancer, with African Americans presenting at a younger age and having a higher incidence and mortality compared with Caucasians (2).

Several risk factors have been implicated in the pathogenesis of laryngeal cancer; the most significant are tobacco and alcohol consumption (4). Tobacco use has been shown to have a linear association with the development of laryngeal cancer, with a risk for smokers that is 10 to 15 times higher than the risk for nonsmokers, and the heaviest smokers have as much as a 30 times greater risk. Research has also demonstrated a linear relationship between the amount of alcohol consumed and the risk of laryngeal cancer. In a study that examined the role of alcohol and tobacco in laryngeal cancer, the multivariate odds ratio was 2.46 for nonsmoking heavy drinkers (defined as $>8$ drinks per day) and 9.38 for nondrinking smokers (511). It has also been shown that alcohol and tobacco have a multiplicative effect on the risk of laryngeal cancer.

Exposure to other environmental factors is thought to potentially increase the risk of LSCC, such as asbestos, polycyclic aromatic hydrocarbons, and textile dust (12). Dietary factors have also been noted, with red meat increasing the risk of laryngeal cancer, while a diet varied in fruit and vegetables potentially has a protective effect. The role that both gastroesophageal and laryngopharyngeal reflux play in the disease process is still controversial and under investigation.

Although the human papillomavirus (HPV) is a proven driver of the majority cancers of the oropharynx, it was initially thought that the virus did not play a role in laryngeal cancer (13-18). However, new research demonstrates the presence of HPV and/or the surrogate marker p16 (cyclindependent kinase inhibitor 2A/multiple tumor suppressor 1) in a minority of laryngeal tumors, although the biologic and prognostic relevance of this finding is unclear. It is estimated that the prevalence of HPV ranges from $20 \%$ to $30 \%$ in laryngeal cancer; however, this percentage varies widely between studies and depends on the detection method used. More work is needed to determine the clinical relevance of $\mathrm{HPV} / \mathrm{p} 16$-positive status in laryngeal cancer, as this remains controversial (13-21).

Approximately $60 \%$ of patients present with advanced (stage III or IV) disease at diagnosis. Unfortunately, laryngeal cancer is one of the few oncologic diseases in which the 5 -year survival rate has decreased over the past 40 years, from $66 \%$ to $63 \%$, although the overall incidence is declining. This highlights the need for further research and innovation in the field $(5,22-24)$. Among the causes of the low survival rate are the lack of screening methods (clinical examination remains the single solution to early detection) and the late presentation of patients to the specialist as a result of little worrying symptoms (hoarseness). The lack of suspicion of cancer at the first consultation is associated with delay in the second consultation among patients who were not diagnosed with cancer initially $(1,25)$.

\section{CYTOKINES IN HEAD AND NECK CANCER}

It has been reported that changes in the expression of cytokines and growth factors may have implications in the malignant transformation of many cancers including head and neck squamous cell carcinoma (HNSCC) and, more recently, $\operatorname{LSCC}(2,26)$. Cytokines are a group of soluble, low-molecular-weight proteins that mediate immune and inflammatory responses. Cytokines are classified into three groups: T-helper 1 (Th1), T-helper 2 (Th2) and T-helper 17 (Th17), as determined by their biological properties (27). Th1 cytokines stimulate cellular immune responses, while Th2 cytokines predominantly regulate humoral responses. Th17 is currently known to regulate inflammatory responses and plays several roles in autoimmunity (27). Cytokines are also classified as pro-inflammatory (IL-1, IL-6, IL-8), tumor necrosis factor-alpha (TNF- $\alpha$ ), interferon (IFN)- $\gamma$ and antiinflammatory cytokines (IL-4, IL-10), tumor growth factorbeta (TGF- $\beta$ ), and vascular endothelial growth factor (VEGF) (28). As for nerve growth factor (NGF), several studies led to divergent hypotheses about the role of NGF, its specific distribution pattern within the tissues and its implication in induction as well as progression of carcinogenesis. However, other recent studies have shown that NGF may have direct clinical relevance in certain tumor cell prevention (29-32).

Involvement of cytokines in the pathogenesis of cancer, and especially HNSCC, has been investigated in a number 
of recent studies (33-36). These studies have categorized cytokines as (a) factors that affect tumor growth, (b) factors that can be used as prognostic markers and (c) those that are possible immunotherapeutic targets (37). Although the main source of cytokines are immune cells, many tumor cells have been shown to make autocrine mediators to support their own growth thus evading the immune response (38); they include HNSCC that produce IL-4, IL-6, IL-8, IL-10, granulocyte macrophage-colony-stimulating factor (GM-CSF), VEGF, prostaglandin E2 (PGE2) as well as basic fibroblast growth factor (bFGF).

It has been hypothesized that some of these cytokines may be used as additional diagnostic markers in the sera of patients because of their excessive production by the tumor cells (39). This could be of great value since there are currently no reliable markers to predict either tumor development or relapse in treated HNSCC patients. Recent studies have demonstrated that HNSCC is associated to a decrease in Th1 and an increase in Th2 cytokine levels, which is thought to be used as a mechanism to evade anti-tumor immune response. In fact, this shift towards the Th2 cytokine response is a common event in HNSCC and many other solid tumors, such as colorectal cancer, renal cell carcinoma, prostate cancer, and melanoma. Therefore, current studies in search of immunotherapeutic approaches to cancer aim to shift the balance in favor of Th1 response.

\section{NEUTROPHIL-TO-LYMPHOCYTE RATIO}

An increased neutrophil-to-lymphocyte ratio (NLR) is associated with poorer prognostic outcomes in numerous types of cancer, including HNSCC (40-43). However, a small number of studies have demonstrated the prognostic role of NLR in patients with laryngeal cancer (44). The association between NLR and survival outcomes in 654 patients with LSCC was evaluated (45) and the authors reported that blood and biochemical parameters, including NLR, plateletto-lymphocyte ratio and albumin-to-globulin ratio were associated with clinical characteristics of the patients, with the exception of histologic grade. Survival analysis demonstrated that NLR at cutoff values subdivided patients into different survival outcomes; subsequent to adjustments for age and other clinical features, NLR was identified to be an independent prognostic factor for overall survival and progression-free survival. Increased levels of cytokines, including IL-6 and IL-8 in tumor tissues were associated with NLR values. In summary, pre-treatment NLR was associated with the prognostic outcomes for patients with laryngeal cancer and may assist to establish prognostic factors for these patients.

\section{INTERLEUKIN-8}

Interleukin-8, a pro-inflammatory factor of the CXC chemokine family that was originally classified as neutrophil chemoattractant, is now reported to play an important role in cancer invasion, angiogenesis and metastasis (46-51). The cancer cells themselves can also secret IL-8 in an autocrine or paracrine manner, such as in breast cancer, gastric cancer, colon cancer, cervical cancer, pancreatic cancer and leukemia (52). Moreover, in human colon cancer cell lines, constitutive expression of IL- 8 has been linked to metastatic potential and has been suggested to play a role in the development of distant metastases. In vivo analysis also showed that IL-8 would be a sensitive marker in predicting prognosis and monitoring disease progression of the pancreatic cancer patients (52).

\section{INTERLEUKIN-8 IN HEAD AND NECK CANCER}

One of the factors that is known to positively drive metastasis is angiogenesis, which has been reported to be associated with decreased survival of HNSCC patients (2, 53-55). IL-8, along with other factors produced either by normal or malignant cells such as VEGF and bFGF has been shown to contribute to angiogenesis, tumorigenesis, and metastasis in patients with $\operatorname{HNSCC}(2,33,56)$.

Serum levels of IL-8 are consistently elevated in patients with recurrent or metastatic SCCHN and elevated levels may correlate with advanced or aggressive disease (34, $36,57)$; in general, IL-8 production is linked with tumor vascularization, metastatic phenotype, tumor growth, and overall poor prognosis. A clear switch from cytokine Th1 to cytokine Th2 in HNSCC patients, low levels of IL-2 and IFN- $\gamma$ in advanced stages, as well as a positive correlation of increased levels of both IL-2 and IL-12 with the early stages of laryngo-pharyngeal cancer were reported (58). Loco-regional metastases were correlated with increased levels of IL-8 and IL-10 and drastic decrease of IFN- $\gamma$. In advanced cancer stages, it has been found that the most affected were IL-2 and IFN- $\gamma$ correlated with increased levels of Th2 cytokines, supporting the hypothesis that the ratio between different Th1 and Th2 cytokines could represent a useful marker for clinical and pathological evaluation of cancer patients.

Interleukin-8 can be significantly triggered by SDF-1/ CXCR4 interaction in HNSCC and its secretion is regulated by Akt phosphorylation after SDF-1 stimulation (59). These 
results point out the importance of SDF-1/CXCR4 interaction in HNSCC angiogenesis and provides a new targeting therapy utility, disrupting SDF-1/CXCR4 interaction combined with downstream-induced angiogenic factors in HNSCC would be beneficial to improve clinical outcome.

According to Swenson and colleagues IL-8 and VEGF expression is based on interactions between NF-kB, AP-1, and NF-IL6 (60). They identified at least 1.5 -fold dose-dependent induction of AP-1, VEGF, and IL-8 promoter/reporter gene activity after 24-hour exposure to cigarette smoke condensate (CSC) reporting that tobacco carcinogens up-regulate AP-1 activity and AP-1 dependent IL-8 and VEGF gene expression in head and neck cancer (60). This up-regulation may promote an angiogenic phenotype that favors invasion in both premalignant and squamous cancer cells of the head and neck. CSC could therefore significantly stimulate AP-1 activation of both genes, resulting in increased IL-8 and VEGF secretion, and these processes could be down-regulated with introduction of a dominant negative A-Fos gene. These data demonstrate a role for tobacco carcinogen stimulation of proangiogenic cytokines, thus promoting an environment suitable for development and metastatic spread of head and neck cancer cells.

\section{INTERLEUKIN-8 IN LARYNGEAL CANCER}

The role of IL-8 in the development and progression of LSCC has been recently investigated (61). In the last decade, four studies focused on the role of IL-8 in LSCC, enrolling a total of 214 patients with laryngeal cancer, and 6 patients with laryngeal dysplasia $(52,58,62,63)$. IL-8 sample was taken by peripheral venous blood, while the types of assays for IL-8 measurement were ELISA kits. The main results of these studies are summarized in Table 1.

Eyigor et al investigated the relationship between the size of tumors, lymph node metastases, stage, differentiation and cytokine levels and reported no significant differences between these variables. IL-8 level in patients affected by laryngeal cancer ranged from $24.9 \mathrm{pg} \backslash \mathrm{ml}$ (52) to $227.15 \mathrm{pg} \backslash \mathrm{ml}$ (62). Patients with laryngeal dysplasia presented $24.02 \mathrm{pg} \backslash \mathrm{ml}$. IL-8 cytokine level in controls reached the maximum of 34.33 (62). These results are in line with two previous studies (33, 38), although they focused on HNSCC and did not specify how many patients had laryngeal cancer compared with other sites in head and neck (38). Similarly, Druzgal et al (34) and Hathaway et al (36) also demonstrated some elevation in IL8 , although without statistical significance. Contrary to the findings of Eyigor et al, Gokhale (57) reported that IL-8 was not elevated in newly diagnosed patients but in patients with recurrence and metastasis of HNSCC. Likewise, Hathaway et al (36) also reported that, although IL-8 is not markedly increased in cancer patients, it is associated with the tumor size. Serum IL-8 level of patients with LSCC was associated with lymph node metastasis and T classification (52). High levels of IL-8 were not significantly associated with shorter overall survival and progression-free survival. Univariate and multivariate analyses showed that high IL-6 serum level, contrarily to IL-8, was an independent adverse prognostic variable for progression free and overall survival (52).

Patients with T2 pharyngeal cancer showed that the average value of IL-8 was much higher than in patients with T2 stage laryngeal cancer (58). In exchange, in T3 group, nearly $25 \%$ of patients exhibiting high or detectable levels of IL-8 had laryngeal cancer. Concerning the Th1/Th2 levels according to loco-regional metastases, the authors identified a specific pattern consisting in a low level of IFN- $\gamma$ and high levels of IL-8 and IL-10. Serum level of IL-8 was high in patients with loco-regional metastases and was low, although noticeable, in patients with reactive nodes. Loco-regional metastases were correlated with a specific cytokine pattern consisting of increased levels of IL- 8 and IL-10 and a drastic decrease in IFN- $\gamma$, demonstrating that the alteration of the immunological balance in these patients with the activation of an immune response may be inefficient to exclude metastatic processes. The switch towards a Th2-type response in advanced cancer patients and the high levels of IL-8 and IL-10 could be responsible of promoting the tumor growth through contiguity. The higher level of IL-8 in patients with loco-regional metastases demonstrates the importance of this cytokine as an indicator of the presence of local metastases, potentially contributing to the correct evaluation of patients and an adequate therapy selection.

The presence of a significant positive relationships between TNF-receptor-associated-factor (TRAF)- 6 mRNA expression and IL-8 secretion when stimulated with phytohaemagglutinin (PHA) in patients with laryngeal carcinomas (63). These authors found that patients with carcinomas characterized by the highest TRAF6 mRNA expression had higher IL-8 concentration. They also noted the positive relationship between toll-like receptor-4 (TLR-4) mRNA status and IL-8 concentration, but this association had borderline statistical significance. This data is in agreement with other studies reporting a higher of TLR4 activity on inflammatory cells 
Table 1. Recent studies that investigated the role of interleukin-8 (IL-8) in laryngeal squamous cell carcinoma (LSCC). The studies included 214 patients with laryngeal cancer and 6 patients with laryngeal dysplasia.

\begin{tabular}{|c|c|c|c|c|c|}
\hline Reference & № of patients & $\begin{array}{l}\text { Sample taken; } \\
\text { types of } \\
\text { assays for IL-8 } \\
\text { measurement }\end{array}$ & $\begin{array}{l}\text { Cytokine levels in patients; Mean } \\
\pm \text { SE (pg/ml) }\end{array}$ & $\begin{array}{l}\text { Cytokine } \\
\text { levels in } \\
\text { controls; } \\
\text { Mean } \pm \text { SE } \\
(\mathrm{pg} / \mathrm{ml})\end{array}$ & Comments \\
\hline $\begin{array}{l}\text { Eyigor et al } \\
\text { (2014) (62) }\end{array}$ & $\begin{array}{l}17 \text { patients with } \\
\text { LSCC; } 6 \text { patients } \\
\text { with laryngeal } \\
\text { dysplasia; } 22 \\
\text { healthy controls }\end{array}$ & $\begin{array}{l}\text { Peripheral } \\
\text { venous blood } \\
\text { samples; ELISA }\end{array}$ & $\begin{array}{l}\text { Levels of IL-8: } 227.15 \pm 81.19 \text { in } \\
\text { patients with L SCC }(p<0.05) \text {; } \\
24.02 \pm 11.57 \text { in patients with } \\
\text { laryngeal dysplasia; }\end{array}$ & $\begin{array}{l}\text { Levels of IL-8: } \\
34.33 \pm 12.60\end{array}$ & $\begin{array}{l}\text { No significant difference between } \\
\text { tumor size, lymph node metastases, } \\
\text { stage, differentiation and cytokine } \\
\text { levels }\end{array}$ \\
\hline $\begin{array}{l}\text { Hao et al } \\
\text { (2013) (52) }\end{array}$ & $\begin{array}{l}92 \text { patients with } \\
\text { primary diagnosis } \\
\text { of LSCC; } \\
50 \text { age and } \\
\text { gender matched } \\
\text { healthy blood } \\
\text { donors with no } \\
\text { previous cancer } \\
\text { history served as } \\
\text { healthy controls. } \\
\end{array}$ & $\begin{array}{l}\text { Peripheral } \\
\text { venous blood } \\
\text { samples; ELISA }\end{array}$ & $24.9[3.6-56.0],(p<0.0001)$ & $\begin{array}{l}14.5[2.3-42.6] \\
(p<0.0001)\end{array}$ & $\begin{array}{l}\text { Serum levels of IL-8 were only } \\
\text { associated with lymph node } \\
\text { metastasis }(p=0.01) \text { and T } \\
\text { classification }(p=0.011)\end{array}$ \\
\hline $\begin{array}{l}\text { Bleotu et al } \\
(2013)(58)\end{array}$ & $\begin{array}{l}50 \text { patients with } \\
\text { laryngeal }(n=41) \\
\text { or pharyngeal } \\
(n=9) \text { cancer }\end{array}$ & $\begin{array}{l}\text { Peripheral } \\
\text { venous blood } \\
\text { samples; ELISA }\end{array}$ & $123.47 \pm 282.66$ & $0.0 \pm 0.0$ & $\begin{array}{l}\text { Loco-regional metastases were } \\
\text { correlated with increased levels of } \\
\text { IL- } 8 \text { and IL-10 and drastic decrease } \\
\text { of IFNr. }\end{array}$ \\
\hline $\begin{array}{l}\text { Starska et al } \\
(2012)(63)\end{array}$ & $\begin{array}{l}55 \text { patients with } \\
\text { LSCC. The control } \\
\text { group of healthy } \\
\text { donors consisted } \\
\text { of } 51 \text { individuals. }\end{array}$ & $\begin{array}{l}\text { Peripheral } \\
\text { blood } \\
\text { mononuclear } \\
\text { cells; ELISA }\end{array}$ & $\begin{array}{l}119.69 \pm 29.95 \mathrm{ng} / \mathrm{mL} \text {; } \\
\text { proinflammatory cytokine } \\
\text { production following mitogenic } \\
\text { stimulation was } 231.56 \pm 29.95 \mathrm{ng} / \\
\mathrm{mL} \text {. The secretion pattern of } \\
\text { carcinomas with the invasion } \\
\text { of cartilage was } 97.4 \pm 18.81 \mathrm{ng} / \mathrm{mL} \text {, } \\
\text { as well as } 243.5 \pm 81.77 \mathrm{ng} / \\
\mathrm{mL} \text { with mitogenic stimulation. } \\
\text { Proinflammatory cytokine } \\
\text { production of tumors characterized } \\
\text { by mode of invasion with no } \\
\text { distinct borderlines was } 139.5 \pm \\
53.33 \mathrm{ng} / \mathrm{mL} \text {, as well as } 266.9 \pm \\
84.45 \mathrm{ng} / \mathrm{mL} \text { following mitogenic } \\
\text { stimulation, respectively. In } \\
\text { carcinomas with } 14-17 \text { points TFG } \\
\text { was } 122.5 \pm 38.24 \mathrm{ng} / \mathrm{mL} \text {, as well as } \\
270.5 \pm 56.17 \mathrm{ng} / \mathrm{mL} \text { in experiments } \\
\text { with mitogenic stimulation. }\end{array}$ & & $\begin{array}{l}\text { In all cases of LSCC the evaluation } \\
\text { of proinflammatory cytokine } \\
\text { expression, disclosed the presence } \\
\text { of significant positive relationships } \\
\text { between TRAF6 mRNA expression } \\
\text { and IL-8. secretion when } \\
\text { stimulated with PHA ( } r=0.83 \text {, } \\
p=0.009 \text { ). Patients with carcinomas } \\
\text { characterized by the highest } \\
\text { TRAF6 mRNA expression, were } \\
\text { found to demonstrate higher IL-8 } \\
\text { concentration. It was also noted } \\
\text { a positive relationship between } \\
\text { TLR4 mRNA status and IL-8 } \\
\text { concentration, but this association } \\
\text { had borderline statistical } \\
\text { significance ( } r=0.67, p=0.06) \text {. }\end{array}$ \\
\hline
\end{tabular}


from patients with laryngeal carcinomas (64). Specifically, more invasive laryngeal carcinomas characterized by a higher disseminated tumor invasion (with no distinct borderlines of the tumor front or with diffuse growth), demonstrated a lower mRNA expression of each TLR pathway molecule in immunocompetent cells. Moreover, it was observed that the more advanced histological laryngeal neoplasm (with higher scores according to TFG total points), the lower TLR4 and TRAF6 mRNA expression in peripheral blood mononuclear cells. This data is in agreement with the findings of studies reporting that the TLR pathway molecules are the key mediators of immune mechanisms, which result in activation of antigen-specific immunity, leading to production of the proinflammatory mediators (63). Higher whole blood levels of IL-6, IL- 8 and TNF- $\alpha$ were related to a higher activity of TLR signaling molecules, connected with a less disseminated invasion of laryngeal carcinomas. These findings demonstrate evidence of unsuppressed anti-tumor immunological response in these types of neoplasms. Moreover, these results suggest the presence of alterations in immunological activity and changes in the secretion of proinflammatory cytokines by circulating immunocompetent cell, which lead to inhibition of tumor progression in advanced laryngeal cancer. Based on these preliminary findings, it could be hypothesized that the TLR signaling molecules might be good potential biomarkers of tumor behavior in LSCC as they could potentially determine the aggressiveness of laryngeal cancer acting through regulatory mechanisms of interleukin production.

\section{CONCLUSIONS}

The mechanisms of cancer origin, invasion, and metastasis is one of the emergent and most promising scientific fields in head and neck cancer, especially in LSCC. Tumor, lymph node and metastasis (TNM) classification is not sufficient for the estimation of tumor aggressiveness; moreover, different conclusions may result from a heterogeneous group of investigated HNSCC cancers in different locations such as oral cancers, laryngopharyngeal carcinomas, nasal cavities and paranasal sinuses tumors (1, 4, 22-24, 65-68).. Biomarkers such as IL-8 deserve further investigation as they could have a role as a screening test for head and neck cancer. To date, there is little and still contrasting evidence on the role of IL-8 in LSCC; however, preliminary data available in the literature are encouraging and could suggest a role for IL-8 as a support of the clinical decisions for appropriate therapy and postoperative care in individual patients affected by laryngeal cancer.

\section{CONFLICT OF INTEREST STATEMENT}

The authors certify that they have no affiliations with or involvement in any organization with any financial interest in the subject matter discussed in this review article.

\section{ACKNOWLEDGEMENTS}

We apologize to the authors of many relevant articles that were not quoted here for reasons of brevity.

\section{REFERENCES}

1. Obid R, Redlich M, Tomeh C. The treatment of laryngeal cancer. Oral Maxillofac Surg Clin North Am 2019; 31(1): 1-11. DOI:10.1016/j.coms.2018.09.001

2. Pries R, Wollenberg B. Cytokines in head and neck cancer. Cytokine Growth Factor Rev 2006; 17(3): 141-146. DOI:10.1016/j.cytogfr.2006.02.001

3. De Virgilio A, Ralli M, Longo L, Mancini P, Attanasio G, Atturo F, et al. Electrochemotherapy in head and neck cancer: A review of an emerging cancer treatment. Oncol Lett 2018; 16(3): 3415-3423. DOI:10.3892/ol.2018.9140

4. Marur S, Forastiere AA. Head and neck squamous cell carcinoma: Update on epidemiology, diagnosis, and treatment. Mayo Clin Proc 2016; 91(3): 386-396. DOI:10.1016/j.mayocp.2015.12.017

5. Steuer CE, El-Deiry M, Parks JR, Higgins KA, Saba NF. An update on larynx cancer. CA Cancer J Clin 2017; 67(1): 31-50. DOI:10.3322/caac.21386

6. Ciafre S, Carito V, Ferraguti G, Greco A, Chaldakov GN, Fiore M, et al. How alcohol drinking affects our genes: an epigenetic point of view. Biochem Cell Biol 2018. DOI:10.1139/bcb-2018-0248

7. Attilia F, Perciballi R, Rotondo C, Capriglione I, Iannuzzi S, Attilia ML, et al. Pharmacological treatment of alcohol use disorder. Scientific evidence. Riv Psichiatr. 2018; 53(3): 123-127. DOI:10.1708/2925.29414

8. Ceccanti M, Iannitelli A, Fiore M. Italian Guidelines for the treatment of alcohol dependence. Riv Psichiatr 2018; 53(3): 105-106. DOI:10.1708/2925.29410

9. Ceccanti M, Coriale G, Hamilton DA, Carito V, Coccurello $\mathrm{R}$, Scalese B, et al. Virtual Morris task responses in individuals in an abstinence phase from alcohol. Can J Physiol Pharmacol. 2018; 96(2): 128-136. DOI:10.1139/ cjpp-2017-0013

10. Ferraguti G, Ciolli P, Carito V, Battagliese G, Mancinelli $\mathrm{R}$, Ciafre $\mathrm{S}$, et al. Ethylglucuronide in the urine as a marker of alcohol consumption during pregnancy: Comparison 
with four alcohol screening questionnaires. Toxicol Lett 2017; 275: 49-56. DOI:10.1016/j.toxlet.2017.04.016

11. Ceccanti M, Hamilton D, Coriale G, Carito V, Aloe L, Chaldakov G, et al. Spatial learning in men undergoing alcohol detoxification. Physiol Behav 2015; 149: 324-330. DOI:10.1016/j.physbeh.2015.06.034

12. Ferster APO, Schubart J, Kim Y, Goldenberg D. Association between laryngeal cancer and asbestos exposure: A systematic review. JAMA Otolaryngol Head Neck Surg 2017; 143(4): 409-416. DOI:10.1001/ jamaoto.2016.3421

13. Bychkov VA, Nikitina EG, Ibragimova MK, Kaigorodova EV, Choinzonov EL, Litviakov NV. Comprehensive metaanalytical summary on human papillomavirus association with head and neck cancer. Exp Oncol. 2016; 38(2): 68-72.

14. Syrjanen S, Rautava J, Syrjanen K. HPV in head and neck cancer - 30 years of history. Recent Results Cancer Res 2017; 206: 3-25. DOI:10.1007/978-3-319-43580-0_1

15. Shaikh MH, McMillan NA, Johnson NW. HPV-associated head and neck cancers in the Asia Pacific: A critical literature review and meta-analysis. Cancer Epidemiol. 2015; 39(6): 923-938. DOI:10.1016/j.canep.2015.09.013

16. Bologna-Molina RE, Castaneda-Castaneira RE, MolinaFrechero N, Perez-Rodriguez E. Human papilloma virus and its association with oral cancer. Rev Med Inst Mex Seguro Soc 2006; 44(2): 147-153.

17. Li X, Gao L, Li H, Gao J, Yang Y, Zhou F, et al. Human papillomavirus infection and laryngeal cancer risk: a systematic review and meta-analysis. J Infect Dis. 2013; 207(3): 479-488. DOI:10.1093/infdis/jis698

18. Tribius S, Wurdemann N, Laban S, Sharma SJ, Wagner S, Hoffmann TK, et al. Update on HPV-associated head and neck cancer-highlights of the 2018 ASCO Annual Meeting. HNO. 2018; 66(12): 888-895. DOI:10.1007/ s00106-018-0577-3

19. Wittekindt C, Wuerdemann N, Gattenlohner S, Brobeil A, Wierzbicka M, Wagner S, et al. The role of high-risk human papillomavirus infections in laryngeal squamous cell carcinoma. Eur Arch Otorhinolaryngol 2017; 274(11): 3837-3842. DOI:10.1007/s00405-017-4718-1

20. Mallen-St Clair J, Alani M, Wang MB, Srivatsan ES. Human papillomavirus in oropharyngeal cancer: The changing face of a disease. Biochim Biophys Acta. 2016; 1866(2): 141-150. DOI:10.1016/j.bbcan.2016.07.005

21. Arndt O, Johannes A, Zeise K, Brock J. [High-risk HPV types in oral and laryngeal papilloma and leukoplakia].
Laryngorhinootologie. 1997; 76(3): 142-149. 10.1055/s2007-997403

22. de Vincentiis M, De Virgilio A, Bussu F, Gallus R, Gallo A, Bastanza G, et al. Oncologic results of the surgical salvage of recurrent laryngeal squamous cell carcinoma in a multicentric retrospective series: emerging role of supracricoid partial laryngectomy. Head Neck. 2015; 37(1): 84-91. DOI:10.1002/hed.23563

23. Bussu F, Paludetti G, Almadori G, De Virgilio A, Galli $\mathrm{J}$, Micciche F, et al. Comparison of total laryngectomy with surgical (cricohyoidopexy) and nonsurgical organpreservation modalities in advanced laryngeal squamous cell carcinomas: A multicenter retrospective analysis. Head Neck. 2013; 35(4): 554-561. DOI:10.1002/ hed.22994

24. De Virgilio A, Fusconi M, Gallo A, Greco A, Kim SH, Conte $\mathrm{M}$, et al. The oncologic radicality of supracricoid partial laryngectomy with cricohyoidopexy in the treatment of advanced N0-N1 laryngeal squamous cell carcinoma. Laryngoscope 2012; 122(4): 826-833. DOI: 10.1002/lary.23178

25. Patel KB, Nichols AC, Fung K, Yoo J, MacNeil SD. Treatment of early stage Supraglottic squamous cell carcinoma: meta-analysis comparing primary surgery versus primary radiotherapy. J Otolaryngol Head Neck Surg 2018; 47(1): 19. DOI:10.1186/s40463-018-0262-2

26. Mantovani A, Allavena P, Sica A, Balkwill F. Cancerrelated inflammation. Nature 2008; 454(7203): 436-444. DOI:10.1038/nature07205

27. Akdis M, Burgler S, Crameri R, Eiwegger T, Fujita H, Gomez E, et al. Interleukins, from 1 to 37, and interferongamma: receptors, functions, and roles in diseases. $J$ Allergy Clin Immunol. 2011; 127(3): 701-721 e701-770. DOI:10.1016/j.jaci.2010.11.050

28. Wang F, Arun P, Friedman J, Chen Z, Van Waes C. Current and potential inflammation targeted therapies in head and neck cancer. Curr Opin Pharmacol. 2009; 9(4): 389-395. DOI:10.1016/j.coph.2009.06.005

29. Aloe L, Rocco ML, Balzamino BO, Micera A. Nerve growth factor: role in growth, differentiation and controlling cancer cell development. J Exp Clin Cancer Res 2016; 35(1): 116. DOI:10.1186/s13046-016-0395-y

30. Fiore M, Chaldakov GN, Aloe L. Nerve growth factor as a signaling molecule for nerve cells and also for the neuroendocrine-immune systems. Rev Neurosci 2009; 20(2): 133-145. 
31. Aloe L, Manni L, Properzi F, De Santis S, Fiore M. Evidence that nerve growth factor promotes the recovery of peripheral neuropathy induced in mice by cisplatin: behavioral, structural and biochemical analysis. Auton Neurosci 2000; 86(1-2): 84-93. DOI:10.1016/S15660702(00)00247-2

32. De Santis S, Pace A, Bove L, Cognetti F, Properzi F, Fiore $\mathrm{M}$, et al. Patients treated with antitumor drugs displaying neurological deficits are characterized by a low circulating level of nerve growth factor. Clin Cancer Res. 2000; 6(1): 90-95.

33. Linkov F, Lisovich A, Yurkovetsky Z, Marrangoni A, Velikokhatnaya L, Nolen B, et al. Early detection of head and neck cancer: development of a novel screening tool using multiplexed immunobead-based biomarker profiling. Cancer Epidemiol Biomarkers Prev. 2007; 16(1): 102-107. DOI:10.1158/1055-9965.EPI-06-0602

34. Druzgal CH, Chen Z, Yeh NT, Thomas GR, Ondrey FG, Duffey DC, et al. A pilot study of longitudinal serum cytokine and angiogenesis factor levels as markers of therapeutic response and survival in patients with head and neck squamous cell carcinoma. Head Neck. 2005; 27(9): 771-784. DOI:10.1002/hed.20246

35. Mojtahedi Z, Khademi B, Yehya A, Talebi A, Fattahi MJ, Ghaderi A. Serum levels of interleukins 4 and 10 in head and neck squamous cell carcinoma. J Laryngol Otol 2012; 126(2): 175-179. DOI:10.1017/S0022215111002349

36. Hathaway B, Landsittel DP, Gooding W, Whiteside TL, Grandis JR, Siegfried JM, et al. Multiplexed analysis of serum cytokines as biomarkers in squamous cell carcinoma of the head and neck patients. Laryngoscope 2005; 115(3): 522-527. DOI:10.1097/01. mlg.0000157850.16649.b8

37. Topping KP, Fletcher LM, Agada FO, Alhamarneh O, Stafford ND, Greenman J. Head and neck tumour immunology: basic concepts and new clinical implications. J Laryngol Otol 2009; 123(1): 9-18. DOI:10.1017/ S0022215108003368

38. Hoffmann TK, Sonkoly E, Homey B, Scheckenbach K, Gwosdz C, Bas M, et al. Aberrant cytokine expression in serum of patients with adenoid cystic carcinoma and squamous cell carcinoma of the head and neck. Head Neck. 2007; 29(5): 472-478. DOI:10.1002/hed.20533

39. Riedel F, Zaiss I, Herzog D, Gotte K, Naim R, Hormann $\mathrm{K}$. Serum levels of interleukin-6 in patients with primary head and neck squamous cell carcinoma. Anticancer Res.
2005; 25(4): 2761-2765.

40. Yang L, Huang Y, Zhou L, Dai Y, Hu G. High pretreatment neutrophil-to-lymphocyte ratio as a predictor of poor survival prognosis in head and neck squamous cell carcinoma: A systematic review and meta-analysis. Head Neck 2018. DOI:10.1002/hed.25583

41. Tham T, Bardash Y, Herman SW, Costantino PD. Neutrophil-to-lymphocyte ratio as a prognostic indicator in head and neck cancer: A systematic review and meta-analysis. Head Neck. 2018; 40(11): 2546-2557. DOI:10.1002/hed.25324

42. Takenaka Y, Oya R, Kitamiura T, Ashida N, Shimizu $\mathrm{K}$, Takemura K, et al. Prognostic role of neutrophilto-lymphocyte ratio in head and neck cancer: A metaanalysis. Head Neck 2018; 40(3): 647-655. DOI:10.1002/ hed.24986

43. Zhao QT, Yang Y, Xu S, Zhang XP, Wang HE, Zhang H, et al. Prognostic role of neutrophil to lymphocyte ratio in lung cancers: a meta-analysis including 7,054 patients. Onco Targets Ther 2015; 8: 2731-2738. DOI:10.2147/ OTT.S90875

44. Mascarella MA, Mannard E, Silva SD, Zeitouni A. Neutrophil-to-lymphocyte ratio in head and neck cancer prognosis: A systematic review and meta-analysis. Head Neck 2018; 40(5): 1091-1100. DOI:10.1002/hed.25075

45. Du J, Liu J, Zhang X, Chen X, Yu R, Gu D, et al. Pretreatment neutrophil-to-lymphocyte ratio predicts survival in patients with laryngeal cancer. Oncol Lett 2018; 15(2): 1664-1672. DOI:10.3892/ol.2017.7501

46. Alfaro C, Sanmamed MF, Rodriguez-Ruiz ME, Teijeira A, Onate C, Gonzalez A, et al. Interleukin-8 in cancer pathogenesis, treatment and follow-up. Cancer Treat Rev. 2017; 60: 24-31. DOI:10.1016/j.ctrv.2017.08.004

47. Maccalli C, Parmiani G, Ferrone S. Immunomodulating and immunoresistance properties of cancer-initiating cells: Implications for the clinical success of immunotherapy. Immunol Invest. 2017; 46(3): 221-238. DOI:10.1080/08 820139.2017.1280051

48. Kotyza J. Interleukin-8 (CXCL8) in tumor associated nonvascular extracellular fluids: its diagnostic and prognostic values. A review. Int J Biol Markers 2012; 27(3): 169-178. DOI:10.5301/JBM.2012.9261

49. Zhu YM, Webster SJ, Flower D, Woll PJ. Interleukin-8/ CXCL8 is a growth factor for human lung cancer cells. Br J Cancer 2004; 91(11): 1970-1976. DOI:10.1038/ sj.bjc. 6602227 
50. Li A, Varney ML, Singh RK. Expression of interleukin 8 and its receptors in human colon carcinoma cells with different metastatic potentials. Clin Cancer Res 2001; 7(10): 3298-3304.

51. Atzpodien J, Kirchner H. Cancer, cytokines, and cytotoxic cells: interleukin-2 in the immunotherapy of human neoplasms. Klin Wochenschr 1990; 68(1): 1-11.

52. Hao W, Zhu Y, Zhou H. Prognostic value of interleukin-6 and interleukin-8 in laryngeal squamous cell cancer. Med Oncol. 2013; 30(1): 333. DOI:10.1007/s12032-012-0333-6

53. Wang Z, Gao ZM, Huang HB, Sun LS, Sun AQ, Li K. Association of IL-8 gene promoter-251 A/T and IL-18 gene promoter-137 G/C polymorphisms with head and neck cancer risk: a comprehensive meta-analysis. Cancer Manag Res. 2018; 10: 2589-2604. DOI:10.2147/CMAR. S165631

54. Guerra EN, Acevedo AC, Leite AF, Gozal D, Chardin H, De Luca Canto G. Diagnostic capability of salivary biomarkers in the assessment of head and neck cancer: A systematic review and meta-analysis. Oral Oncol 2015; 51(9): 805-818. DOI:10.1016/j.oraloncology.2015.06.010

55. Lee KD, Lee HS, Jeon CH. Body fluid biomarkers for early detection of head and neck squamous cell carcinomas. Anticancer Res 2011; 31(4): 1161-1167.

56. Kilic I, Guldiken S, Sipahi T, Palabiyik O, Akker M, Celik O, et al. Investigation of VEGF and IL-8 gene polymorphisms in patients with differentiated thyroid cancer. Clin Lab 2016; 62(12): 2319-2325. DOI:10.7754/ Clin.Lab.2016.160403

57. Gokhale AS, Haddad RI, Cavacini LA, Wirth L, Weeks L, Hallar M, et al. Serum concentrations of interleukin-8, vascular endothelial growth factor, and epidermal growth factor receptor in patients with squamous cell cancer of the head and neck. Oral Oncol. 2005; 41(1): 70-76. DOI:10.1016/j.oraloncology.2004.06.005

58. Bleotu C, Chifiriuc MC, Grigore R, Grancea C, Popescu $\mathrm{CR}$, Anton $\mathrm{G}$, et al. Investigation of Th1/Th2 cytokine profiles in patients with laryngo-pharyngeal, HPV-positive cancers. Eur Arch Otorhinolaryngol 2013; 270(2): 711718. DOI:10.1007/s00405-012-2067-7

59. Li KC, Huang YH, Ho CY, Chu CY, Cha ST, Tsai HH, et $a l$. The role of IL-8 in the SDF-1alpha/CXCR4-induced angiogenesis of laryngeal and hypopharyngeal squamous cell carcinoma. Oral Oncol 2012; 48(6): 507-515. DOI:10.1016/j.oraloncology.2012.01.006

60. Swenson WG, Wuertz BR, Ondrey FG. Tobacco carcinogen mediated up-regulation of AP-1 dependent pro-angiogenic cytokines in head and neck carcinogenesis. Mol Carcinog 2011; 50(9): 668-679. DOI:10.1002/ mc. 20775

61. Melinceanu L, Sarafoleanu C, Lerescu L, Tucureanu C, Caras I, Salageanu A. Impact of smoking on the immunological profile of patients with laryngeal carcinoma. J Med Life 2009; 2(2): 211-218.

62. Eyigor M, Eyigor H, Osma U, Yilmaz MD, Erin N, Selcuk OT, et al. Analysis of serum cytokine levels in larynx squamous cell carcinoma and dysplasia patients. Iran $J$ Immunol 2014; 11(4): 259-268. DOI:IJIv11i4A4

63. Starska K, Forma E, Brys M, Glowacka E, Lewy-Trenda I, Lukomski M, et al. The expression of TLR pathway molecules in peripheral blood mononuclear cells and their relationship with tumor invasion and cytokine secretion in laryngeal carcinoma. Adv Med Sci 2012; 57(1): 124-135. DOI:10.2478/v10039-011-0058-3

64. Szczepanski M, Stelmachowska M, Stryczynski L, Golusinski W, Samara H, Mozer-Lisewska I, et al. Assessment of expression of toll-like receptors 2, 3 and 4 in laryngeal carcinoma. Eur Arch Otorhinolaryngol 2007; 264(5): 525-530. DOI:10.1007/s00405-006-0215-7

65. Ralli M, de Vincentiis M, Greco A. Large parapharyngeal mass: a challenging differential diagnosis. Lancet Oncol 2018 Mar;19(3):e181. DOI:10.1016/S14702045(17)30579-X.

66. Altissimi G, Ralli M, Sementilli G, Fiorentino F, et al. Adult-Type Rhabdomyoma of the Larynx: Clinicopathologic Study of an Uncommon Tumor in a Rare Location. Case Rep Otolaryngol 2017;2017:7186768. DOI:10.1155/2017/7186768

67. Ralli M, de Vincentiis M, Greco A. First, Rule Out Cancer: Giant Lipoma. Am J Med 2018 Feb;131(2):146-147. DOI:10.1016/j.amjmed.2017.09.013.

68. Ralli M, Altissimi G, Turchetta R, Rigante M. Metastatic Renal Cell Carcinoma Presenting as a Paranasal Sinus Mass: The Importance of Differential Diagnosis. Case Rep Otolaryngol 2017;2017:9242374. DOI:10.1155/2017/9242374. 